UDC 658

LBK 65.05

JEL Code D03, D23, M42

\title{
SUBSTANTIATION OF A COMPLIANCE CONTROL OF SOCIALLY SIGNIFICANT ORGANISATIONS ON THE INSTITUTIONAL THEORY BASIS
}

\author{
Vilena A. Yakimova \\ ORCID ID: $\underline{0000-0001-5866-5652}$, Researcher ID: $\underline{\text { O-3883-2017 }}$ \\ E-mail: vilena yakimova@mail.ru \\ Amur State University \\ 21, Ignat'evskoe shosse, Blagoveshchensk, 675027, Russia
}

The issues concerning public welfare and sustainable growth that is possible when economic agents behave conscientiously are currently significant. The main purpose of the present study is to substantiate economically the role and the main points of a compliance control as an institute which aim is to reduce stakeholder's risks and to provide a sustainable growth of socially significant organisations that make a national economy function efficiently. The research is based on a theoretical methodological apparatus of an institutional economic theory, a risk-oriented approach, methods of analysis, systematization and generalization. The novelty of the study is a different view on the concept "a compliance control institute of socially significant organisations" that allows us to estimate the consequences of the low breaking by socially significant organisations that occur in the form of costs growth and risks of agents who are interested in a sustainable and conscientious transaction. The trends and types of the compliance control have been determined. These trends consider a social and economic role of organisations that are being controlled and areas where compliance risks arise. Considering the features of socially significant organisations and their classification we have characterised institutional relations, determined possible conflicts of interest and compliance risks, distinguished the functions of the compliance control institute, revealed the role of an institutional structure of the compliance at three levels (internal, external and public). We have also discovered factors that prevent efficient functioning of the institution. In our research we have proven that the institute of a compliance control is significant to reduce opportunistic behaviour risks that threaten sustainable development of socially significant organisations and their stakeholders. The efficient development of the compliance institute is connected to the need of the state and society to assist in the implementation of functions and mechanism of the enforcement to internal audit and internal control by socially significant organisations. The assessment of the control procedure quality by the socially significant organisations and their opposition to legislation violation risks are also important for the compliance control institute. Further studies will be devoted to the construction of a hierarchy of the compliance control institution with a clear division of control tasks at internal and external levels. Also a set of solutions to increase the efficiency of the implementation of the compliance control functionality will be made.

Keywords: compliance control, institution of a compliance control, stakeholders, socially significant organizations, compliance risks, transaction costs, efficiency, subjects of transactions, dysfunction of the institution.

(C) Yakimova V.A., 2017 


\title{
ОБОСНОВАНИЕ РОЛИ КОМПЛАЕНС-КОНТРОЛЯ ОБЩЕСТВЕННО ЗНАЧИМЫХ ОРГАНИЗАЦИЙ С ПОЗИЦИИ ИНСТИТУЦИОНАЛЬНОЙ ЭКОНОМИЧЕСКОЙ ТЕОРИИ
}

\author{
Вилена Анатольевна Якимова \\ ORCIDID: 0000-0001-5866-5652, ResearcherID: 0-3883-2017 \\ Электронный адрес: vilena_yakimova@mail.ru \\ Амурский государственный университет \\ Россия, 675027, Благовещенск, ул. Игнатьевское шоссе, 21
}

В современных экономических условиях актуальными являются вопросы обеспечения общественного благосостояния и формирования условий устойчивого роста, который возможен при добросовестном поведении экономических агентов в обществе. Основная цель авторского исследования заключается в экономическом обосновании роли и сущности комплаенс-контроля как института, деятельность которого направлена на снижение рисков стейкхолдеров и обеспечение устойчивого развития общественно значимых организаций, которые играют важную роль для эффективного функционирования национальной экономики. Исследование выполнено на основе теоретико-методологического аппарата институциональной экономической теории, риск-ориентированного подхода, методов анализа, систематизации и обобщения. Научную новизну исследования составляет трактовка понятия «институт комплаенс-онтроля общественно значимых организаций», что позволило оценить последствия нарушения законодательства общественно значимыми организациями в виде роста издержек и рисков субъектов, заинтересованных в устойчивом состоянии и добросовестном выполнении трансакций. Определены направления и виды комплаенс-контроля, учитывающие социально-экономическую роль организаций как объектов контроля и области возникновения комплаенс-рисков. С учетом особенностей общественно значимых организаций и разделения их на группы дана характеристика институциональных отношений, определены возможные конфликты интересов и комплаенс-риски, выделены функции института комплаенсконтроля, раскрыта роль институциональной структуры комплаенса на трех уровнях (внутреннем, внешнем и государственном), выявлены факторы, препятствующие эффективному функционированию института. В ходе исследования обосновывается, что институт комплаенс-контроля имеет важное значение для снижения рисков оппортунистического поведения, которые представляют собой угрозы устойчивого состояния общественно значимых организаций и их стейкхолдеров. Эффективное развитие института комплаенса связывается с необходимостью содействия государства и общества в реализации функций и механизма принуждения к созданию общественно значимыми организациями внутреннего и проведению аудиторского контроля, оценке качества контрольных процедур и противодействия рискам нарушения законодательства. Перспективы будущих исследований связаны с построением иерархической структуры института комплаенс-контроля с четким разграничением задач контроля на внутреннем и внешнем уровнях и разработкой комплекса решений по повышению эффективности реализации его функционального назначения.

Ключевые слова: комплаенс-контроль, институт комплаенс-контроля, институциональная структура, стейкхолдеры, общественно значимые организации, комплаенс-риски, трансакционные издержки, эффективность, субъекты трансакций, дисфункция института.

\section{Introduction \\ 7 he strategy of the national economy development aims at safety and sustainable condition.} Its implementation is affected by crisis, corruption, misuse of budget resources and foreign trade sanctions that threaten a sustainable functioning of an economic system. Sustainable development guarantees the protection of national interests, the provision of all sectors of economy with resources, the growth of economic potential and socially oriented economy that leads to the society welfare. The relations among economic agents that arise within economic sectors and during cross-sectoral cooperation in foreign trade, production, labour and social conditions influence the growth of the national economy. Public institutions, the state and commercial organisations that operate in a real economy sector are interested in the efficient functioning of the national economy and in their protection from the unfair behaviour of market subjects. 
To reduce internal and external economic threats, one needs a balanced system to assess, control and manage the risks of economic agents' behaviour that may damage the state and society interests. In this regard special institutions that would guarantee the economy protection from possible threats are formed. These institutions would also assure an economic policy implementation and making efficient ties among economy elements and public structures. A compliance control of socially significant organisations is considered to be one of the efficient mechanisms to provide a sustainable development of economy.

Scientific studies by V.Kh. Valiev [1], V.V. Silakova [2], G.P. Starinov and I.V. Tsevelev [3] describe the role of the compliance in the system of an enterprise management precisely. The works also concern compliance risk assessment and management. Nevertheless, the economic essence and functions of the compliance as an institute of the national economy have not been substantiated enough. The institutional theory is able to explain the essence of transactions among economic agents, their individual and cooperative behaviour that may lead to opportunism risks and cause negative consequences for the economy. Many economists (D. North [4], G.B. Kleiner [5], G. Hodgson [6]) suggest that control and compulsion mechanisms are integral parts of any institution. At the same time others (E.Yu. Itygilova [7], V.V. Pankov [8], P.P. Baranov [9], V.N. Zhukov [10]) convince the importance of an institutionalism but the control is considered to be a separate social and economic institute that meets all the requirements of an institute. Among the requirements are a set of rules and norms, mechanisms that enforce to follow them and the system of sanctions for not compliance of these norms.

The present research of the compliance control is based on the works by Russian and foreign scientists in the field of the contract theory, transactions and opportunistic behaviour by J.K. Commons [11], O.E. Williamson [12], A. Alchian, G. Demsets [13], T. Eggertsson [14], E.G. Furubotn [15], A.E. Shastitko [16], the theory of transaction costs by R.V. Coase
[17], the theory of stakeholders by R.E. Freeman [18], M.C. Jensen and W.H. Meckling [19], the conception of efficient institutions by V.L. Tambovtsev [20] and O.S. Sukharev [21]. The appeal to the institutional theory regulations substantiates the economic role of the compliance control institute of socially significant organisations more precisely. It allows us to reveal its essence, demonstrate functionality, determine an institutional structure of the compliance control and their peculiarities for individual transaction subjects.

\section{The role of the compliance control in the system of institutional relations of socially significant organisations \\ The development of economy is
currently characterised by
internationalization, globalization} in economic life, technological progress, labour resources and capital migration, international specialization and cooperation, innovative and information technologies, vertical integration and territory cluster formation. These tendencies change the conventional attitude to an organisation, its activity purposes and boarders in a socio-economic environment. In this regard the statues and role of socially significant organisations become significant as they are considered to be the driving force of the economy and affect macroeconomic indicators, quality and living standards of the population.

The Ministry of Economic Development of the Russian Federation directs it attention to financial indices of socially significant organisations when developing a macroeconomic policy of the sustainable economic growth. However, the list of socially significant organisations that is discussed at the legislation level and in scientific researches lacks systematisation and signature. For example, according to the $8^{\text {th }}$ Directive of the EU socially significant organisations are considered to be organisations that are of interest to society and a state due to their activity, amount and number of employees. According to the Accounting conception and Auditor Independence Rules socially significant organisations are considered to be economic entities that involve expressly or by implication resources of unrestricted circle of individuals: joint-stock companies; organisations that have 
securities placed publicly; financial organisations working with the resources of natural and juridical persons, organisations with the state ownership share being not less than $25 \%$ in their share capital and other organisations ${ }^{1}$. Organisations are acclaimed to be socially significant due to their economic activity, size and corporate status [22]. Thus, the significance of an organisation being a subject of economic relations is determined by its role in the national economy and its contribution in the public welfare of the country.

Socially significant organisations constantly interact with other economic agents that operate in macro- and microeconomic environment, are socially responsible to the society. The social role of organisations increases if the scope of their activity and their external and internal interaction extend.

In an industrial society a firm is considered to be the main producer of "organisational welfare" that makes goods valuable for all interested persons-stakeholders. This term was firstly introduced by R.E. Freeman [18]. From his point of view a stakeholder is any group or an individual who is able to influence a company activity or is influenced by it. An organisation constantly changing resources, capital or information with the external surroundings makes goods significant for the society, reconciles the conflicting interests with stakeholders, is bound or makes particular expectations and claims against other groups of persons. Suppliers or other trade counteragents, customers of goods (works or services), owners, investors, competitors, banks and other financial institutions, a state are included in the group of stakeholders.

According to the theory of stakeholders every group of interested parties may participate in the trend development of a firm. For example, in the studies by J.K. Galbraith [23], R.E. Freeman [18], R.P. Phillips [24] business is suggested to be "a social organism" the responsible behaviour of which leads to an

\footnotetext{
${ }^{1}$ Accounting conception in the Russian Federation for madium-term outloock: confirmed by order № 180 of the Ministry of Finance of the RF on 01.07.2004; Autitor and Auditing Firm Independence Rules: approved by the Audit Council on 29.09.2012, protocol № 6 .
}

economic stability. According to the corporation theory by J.K. Galbraith [23], an organisation aim is to stability and security of the society as the key privy. Large organisations guarantee industrial society and national economy development whereas transnational ones are responsible for the world economy development.

A new economy model aimed at social welfare growth is characterised as innovative and high-tech. It pays attention to the development of branches and organisations that form knowledge economy and human assets. Under these circumstances the role of strategic and investment significant system-forming organisations that contribute to the GDP of a country increases.

To our mind based on a social and economic role of an organisation in the society several mostly important groups of socially significant organisations may be distinguished to provide sustainable economic development of a country (Table 1). The groups of socially significant organisations presented in Table 1 play a particular social and economic role. They differ in interested parties due to the specificity of resources used, type, character and rate of the activity. The classification of the organisations based on their social and economic significance is necessary to determine key relations and transactions of economic agents with the state authorities, population and other stakeholders. The relations among economic agents that arise because of recourse distribution are aimed at institutional agreement implementation that is significant to make public goods and to solve strategically significant tasks for national economy operation. 
Table 1

Description of socially significant organisation groups

\begin{tabular}{|c|c|c|c|}
\hline $\begin{array}{c}\text { Group } \\
\text { of organisations }\end{array}$ & $\begin{array}{c}\text { Criteria for the group of socially } \\
\text { significant organisations }\end{array}$ & Social and economic importance & $\begin{array}{c}\text { Mostly significant } \\
\text { stakeholders }\end{array}$ \\
\hline $\begin{array}{l}\text { Investment } \\
\text { significant }\end{array}$ & $\begin{array}{l}\text { Public organisations that have } \\
\text { securities listings at Russian and } \\
\text { international stock exchange; } \\
\text { organisations made by foreign capital } \\
\text { share; transnational corporations }\end{array}$ & $\begin{array}{l}\text { Highly profitable and investment attractive } \\
\text { organisations that have an access to foreign } \\
\text { capital markets and determine a country } \\
\text { financial climate, foreign direct investment } \\
\text { flows, financial and external economic } \\
\text { security of a country. They concentrate a } \\
\text { significant part of national resources } \\
\text { (natural, financial, labour with high } \\
\text { qualification rate) }\end{array}$ & $\begin{array}{l}\text { State; investors, } \\
\text { subsidiaries } \\
\text { associated } \\
\text { companies } \\
\text { including foreign } \\
\text { ones }\end{array}$ \\
\hline Export-oriented & $\begin{array}{l}\text { Exporters that produce goods in } \\
\text { accordance to international standards }\end{array}$ & $\begin{array}{l}\text { The organisation activity influences GDP, } \\
\text { key macroeconomic indices, determines a } \\
\text { country competitive ability and a foreign } \\
\text { trade policy }\end{array}$ & Foreign customers \\
\hline System-forming & $\begin{array}{l}\text { Organisations, holding companies and } \\
\text { vertically integrated companies with } \\
\text { the profit that makes more than } 70 \% \\
\text { of the nation's total income and } 20 \% \\
\text { of employees from the total amount of } \\
\text { the employed in the economy }{ }^{2} \text {; state } \\
\text { companies, state corporations }\end{array}$ & $\begin{array}{l}\text { They contribute to budget income in a } \\
\text { form of tax receipts, realize large } \\
\text { investment projects, implement } \\
\text { international treaties and commitments, } \\
\text { have high technological potential, preserve } \\
\text { production infrastructure of a country. } \\
\text { Guarantee population employment as a } \\
\text { public utility activity that brings profit and } \\
\text { increases a nation welfare }\end{array}$ & $\begin{array}{l}\text { Owners, investors, } \\
\text { a state, costumers, } \\
\text { suppliers, } \\
\text { competitors }\end{array}$ \\
\hline $\begin{array}{l}\text { Strategically } \\
\text { significant }\end{array}$ & $\begin{array}{l}\text { Organisations involved in priority } \\
\text { branches of economy (a nano-system } \\
\text { industry, IT systems; promising types } \\
\text { of armament; conservation; robotic } \\
\text { complexes; transport and space } \\
\text { systems; power efficiency, etc.); } \\
\text { organisations implementing strategic } \\
\text { projects for a state and providing } \\
\text { strategic interests; organisations } \\
\text { involved in branches that form } \\
\text { knowledge economy; organisations } \\
\text { included in special economic zones, } \\
\text { industrial and innovation clusters, } \\
\text { priority development areas, financial- } \\
\text { industrial groups }\end{array}$ & $\begin{array}{l}\text { They determine a nation innovation } \\
\text { development, scientific-and-technological } \\
\text { advance. These organisations are } \\
\text { significant to implement an economic } \\
\text { strategy of business integration and to } \\
\text { make clusters to increase economic } \\
\text { efficiency and attracts investments, venture } \\
\text { capital, to form highly qualified human } \\
\text { capital. Innovative technologies, } \\
\text { intellectual capital are the trends that } \\
\text { increase a nation welfare, allocate profit } \\
\text { and resources socially fair }\end{array}$ & $\begin{array}{l}\text { Regional } \\
\text { authorities, owners, } \\
\text { investors, a state, } \\
\text { costumers, } \\
\text { suppliers }\end{array}$ \\
\hline $\begin{array}{l}\text { Organisations } \\
\text { forming a } \\
\text { company town }\end{array}$ & $\begin{array}{l}\text { Organisations (their branches) } \\
\text { included in the single-industry city } \\
\text { list, the average number of the } \\
\text { population in these cities is not less } \\
\text { than } 20 \% \text { of the average number of } \\
\text { employees in all organisations of the } \\
\text { present municipality }\end{array}$ & $\begin{array}{l}\text { They influence the region population } \\
\text { employment rate and social and economic } \\
\text { development of individual territories and } \\
\text { towns }\end{array}$ & Regional authorities \\
\hline
\end{tabular}

\footnotetext{
${ }^{2}$ Information is provided by the Ministry of Economic Development of the RF "State support of systematically important organisations", the list of these organisations was confermed by the Government Committee on economic development and integration on February 5, 2015, № 1 .

${ }^{3}$ The RF government order № 1398-r dated 29.07.2014 (ed. on 13.05.2016) “On the confirmation of the list of single-industry municipalities of the RF (single-industry cities)".
} 


\begin{tabular}{|c|c|c|c|}
\hline & & & The End of Table 1 \\
\hline $\begin{array}{c}\text { Group } \\
\text { of organisations }\end{array}$ & $\begin{array}{c}\text { Criteria for the group of socially } \\
\text { significant organisations }\end{array}$ & Social and economic importance & \begin{tabular}{|c|} 
Mostly significant \\
stakeholders
\end{tabular} \\
\hline $\begin{array}{l}\text { Socially } \\
\text { significant }\end{array}$ & $\begin{array}{l}\text { These organisations produce social } \\
\text { benefit (housing and communal } \\
\text { service sector, education, science, } \\
\text { public health service, culture, social } \\
\text { protection of the population, } \\
\text { protection and justice (courts, offices } \\
\text { of public prosecutors), foodstuffs } \\
\text { trade, roads and transport } \\
\text { infrastructure, agriculture, defence } \\
\text { industry, electricity industry) }\end{array}$ & $\begin{array}{l}\text { These organisations form human capital, } \\
\text { provide public goods the provision and } \\
\text { quality of which influence the population } \\
\text { living standards. They determine social, } \\
\text { food, energy security. The rate increase of } \\
\text { natural monopolies negatively affects the } \\
\text { consumer price growth, industrial } \\
\text { enterprise production cost and raises the } \\
\text { inflation rate in a country }\end{array}$ & $\begin{array}{l}\text { A state (being an } \\
\text { owner of most } \\
\text { organisations), } \\
\text { households, profit- } \\
\text { making and non- } \\
\text { profit organisations }\end{array}$ \\
\hline $\begin{array}{l}\text { Financially } \\
\text { significant }\end{array}$ & $\begin{array}{l}\text { Organisations that provide financial } \\
\text { services to the population and a real } \\
\text { sector of economy (credit, insurance } \\
\text { organisations, professional } \\
\text { participants at a stock market, non- } \\
\text { governmental pension fund, mutual } \\
\text { investment funds, paying agents, } \\
\text { intermediary companies working in } \\
\text { real estate sector) }\end{array}$ & $\begin{array}{l}\text { The organisations activity impacts cash } \\
\text { turnover of a country, accumulates national } \\
\text { financial resources, distributes money } \\
\text { flows among the economic agents }\end{array}$ & $\begin{array}{l}\text { Owners, investors, } \\
\text { households, profit- } \\
\text { making and non- } \\
\text { profit organisations, } \\
\text { a state }\end{array}$ \\
\hline $\begin{array}{l}\text { Ecologically } \\
\text { significant }\end{array}$ & $\begin{array}{l}\text { Organisations which activity } \\
\text { influences the environment: } \\
\text { enterprises of chemical, } \\
\text { petrochemical, metallurgical, } \\
\text { pharmaceutical industries, fuel and } \\
\text { energy complex and other } \\
\text { organisations that are responsible for } \\
\text { ecological standards compliance }\end{array}$ & $\begin{array}{l}\text { They are socially responsible for the } \\
\text { environment protection that suggests } \\
\text { financial participation in nature protection } \\
\text { measures and the implementation of these } \\
\text { measures, it also means rational } \\
\text { environmental management, sustainable } \\
\text { use of raw material and fuel resources, } \\
\text { prevention of accidents and disasters }\end{array}$ & Households, a sate \\
\hline
\end{tabular}

The formation of a compliance control institution in the society is necessary to realize institutional agreement among transaction participants efficiently. Its aim is to prevent and reduce the impact of conflict of interests that may arise among economic agents and negatively impact the national economy.

The concept "institute" has different interpretations - "the system of norms and instructions", "behaviour patterns and images", "the tool that regulates people joint activity", "order and subordination of actions and processes" that determine incentives, mutual expectations, rights and liabilities of economic agents. According to D. North - one of the institutional theory founders - an institute is social life rules or "human made restrictions that form interaction among people" [4]. T. Veblen suggested an institute to be "a thought stereotype", "a usual response to incentives", "a common way of thinking about society and a person interaction and about private functions" [25]. According to G.B. Kleiner's definition an institute is a system of interrelated, relatively sustainable (toward behaviour change or interests of particular agents or their groups) formal and informal standards that continuously function during a significant period of time. These norms regulate decision making, activity and interaction of social and economic agents and their groups [5]. V.V. Dement'ev defines an institute as a social mechanism that concentrates the activity of some people who interact with others making the latter behave in a particular way. As a result the former makes a sustainable social structure or an organisation [26]. Thus, an institute being a form of economic agent interaction assigns behaviour patterns, particular standards and mechanisms to their enforcement in the society. They become the basis for coordination and guarantee conscientious commitment implementations by agents.

Objective human requirements to regulate the activity of economic agents, to prevent conditions, possibilities and facts of irrational resource distribution and illegal 
economic benefits are the background of the compliance control institution invention. G.B. Kleiner has stressed [5] that new institutions are created in accordance to "the intentional and deep ideology of some authoritative part of the society" and they are the results of the existed institution interaction (or pro-institutions).

A compliance control institution is formed on the basis of gradual institutional development of financial and legal control as a result of a society reaction to the growth of economic crimes, corruption increase and unfair behaviour of economic agents at the market that significantly damages the national economy.
Thus, a compliance control institution is a system of interconnected and relatively sustainable formal and informal standards, tools and mechanisms to regulate social and economic relations among economic agents. This regulation is based on the maintenance control of legal acts, business practice norms, standards and rules of their behaviour at the market condition.

The role of the compliance control institution is depicted in Fig. 1. The interconnection among economic agents and their stakeholders as the participants of institutional relations is also presented there.

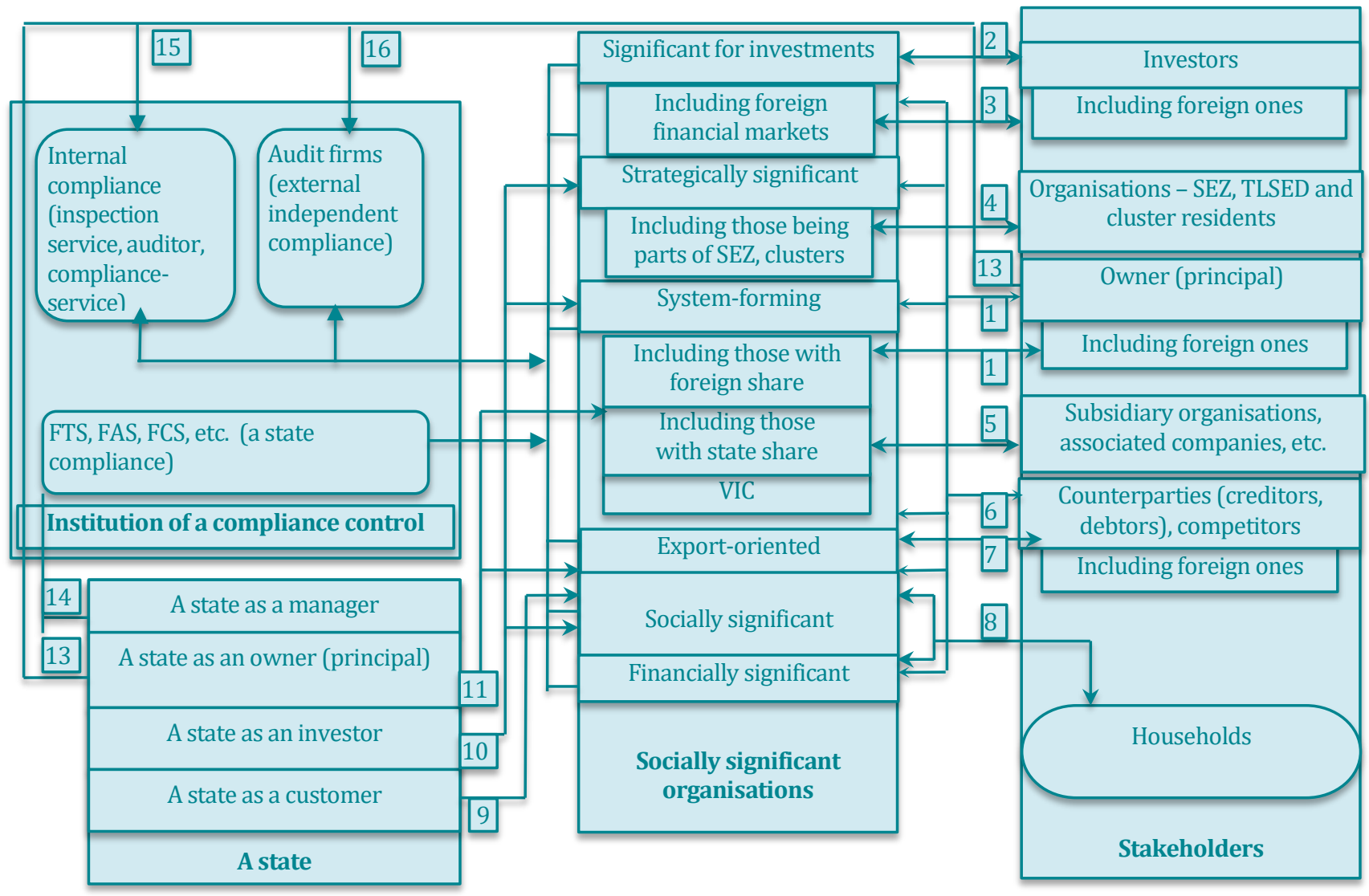

Transactions: 1, 5, 11 - principal-agent (management transaction); 2-3, 10 - investor - investment users (issuers, budget targeted funding recipients) (investment transactions); 4 cluster management company - a cluster resident (management transaction); 6-9 - buyer - seller (trade transaction), 12 - financial and non-financial sector, households- a state (rationing transaction); 13,15 principal (owner/company management) - internal controller - agent (management transaction); 14 - a state - state control service - economic agent (management transaction); 16 - principal/company management - external auditor - agent (trade transaction).

Fig. 1. Compliance-control in the system of institutional relations of socially significant organisations *

* Abbreviations: FTS - Federal Tax Service; FAS - Federal Antimonopoly Serviced; FCS - Federal Customs Service; SEZ- Special economic zones; VIC - vertically integrated companies; TASED - Territory of advance social and economic development.

As we can see from Fig. 1 the groups of socially significant organisations due to their specific activity and social role have institutional relations with other transaction agents that are 
interested in stable and sustainable condition of counteragents and conscientious implementation of contracts. The most important stakeholders that are more interested in financial and economic activity results than other agents may be distinguished for these groups of organisations. In case a socially significant organisation breaks law and business ethic norms, these stakeholders will suffer serious economic losses. And the main task of an economic regulation is to forecast and prevent this damage. For example, households being the main stakeholder of socially and financially significant organisations will incur additional costs to make up losses in case of unfair actions on the part of these organisations or insufficient quality of services. It will result to public policy dissatisfaction due to living standards decrease. The forms of internal, independent external and state control distinguished in Fig.1 focus on the regulation of a corresponding branch of institutional relations. Thus, a state compliance control is conducted by state control authorities in respect of all socially significant organisations but internal and external audit control - of organisation owners and as a rule on the initiative basis.

Besides the role of the compliance control in institutional relations of socially significant organisations is to reduce transaction costs, to prevent information asymmetry during transactions among economic agents and to protect from dishonest behaviour of transaction participants. Information asymmetry means information benefits of one of the parties while the other has incomplete or distorted information. That determines possibilities for opportunistic behaviour.

The "opportunistic behaviour" category was first suggested by O.E. Williamson [12]. Opportunism means to be of own interests rather that the interests of firms of other parties, i.e. to break laws and (or) ethic norms (to shrink or hold-up, to neglect, to use official power, etc.).

Opportunistic behaviour is characterised by the following features:

- conflicting interests of transaction parties, i.e. every economic agent relies on his own interests;

- information asymmetry that causes of opportunism probabilities;
- economic motives to manipulate information asymmetry;

- harm interested parties directly and indirectly (business reputation damage, costs, etc.);

- action premeditation.

The aim of the compliance control as an institute is to prevent and to stop opportunities for opportunistic behaviour of an economic agent, to reduce the rate of negative impact of opportunism on the national economy and public welfare of the population. In this regard the tools and methods of efficient compliance control should focus on risk event study, probability and conditions for them, unfair behaviour motives of institutional relation subjects.

The asymmetry information and opportunism risks at transactions are associated with the "compliance risk" category in modern law and regulatory documents and scientific literature. According to Basel Committee on Banking Supervision the compliance risk is determined to be "the risk of judicial and normative sanctions of regulatory authorities, material and financial losses or reputation damage as a result of law, instruction, rule, standard or behaviour code non-compliance" 4 . According to G.P. Starinova, I.V. Tseveleva [3] compliance-risks may occur as internal and external threatens during interactions among entrepreneurs, society and a state. Consequently, compliance risks of socially significant organisations negatively affect the economy of a state or a region, prevent economic growth and production factor distribution, investment inflows, leads to the increase of illegal production of goods significant for the society. They also result into the growth of transaction costs of economic agents, break competativeness principles, fair income distribution and rationalisation of budget funding, prevent implementation of state programs.

Possible risks and transaction costs for external and internal stakeholders are characterised in Table 2.

\footnotetext{
${ }^{4}$ Regulation on internal control organisation in credit companies and banking groups: confirmed by the Central Bank of the RF on 16.12.2003 № 242-P.
} 
Risk and losses characteristics of external and internal stakeholders at transactions

\begin{tabular}{|c|c|c|c|c|c|c|}
\hline \multirow{2}{*}{$\begin{array}{l}\text { Number of } \\
\text { transaction* }\end{array}$} & \multirow{2}{*}{$\begin{array}{l}\text { Transaction } \\
\text { subjects }\end{array}$} & \multirow{2}{*}{$\begin{array}{l}\text { Possible } \\
\text { conflict of } \\
\text { interests }\end{array}$} & \multicolumn{2}{|c|}{$\begin{array}{c}\text { Economic agents and internal } \\
\text { stakeholders }\end{array}$} & \multicolumn{2}{|c|}{ External stakeholders } \\
\hline & & & Compliance risks & Transaction costs & Risks & $\begin{array}{l}\text { Transaction } \\
\text { costs }\end{array}$ \\
\hline $1,5,11$ & $\begin{array}{l}\text { Principal-agent } \\
\text { (management } \\
\text { transaction) }\end{array}$ & $\begin{array}{l}\text { Profit } \\
\text { allocation, } \\
\text { control and } \\
\text { decision } \\
\text { making, } \\
\text { resources } \\
\text { management, } \\
\text { safety of } \\
\text { property }\end{array}$ & $\begin{array}{l}\text { Sanction risks for } \\
\text { corporate legislation } \\
\text { infringement, } \\
\text { winding-up or } \\
\text { suspension in case of } \\
\text { illegal enterprise, } \\
\text { business reputation } \\
\text { loss, investment } \\
\text { losses }\end{array}$ & $\begin{array}{l}\text { Agency costs of } \\
\text { commitment } \\
\text { execution, control } \\
\text { and monitoring } \\
\text { organisation, } \\
\text { protection from } \\
\text { the third party, } \\
\text { resolve conflicts } \\
\text { of interests, losses } \\
\text { and damage from } \\
\text { sanctions }\end{array}$ & $\begin{array}{l}\text { Risk of not to get } \\
\text { dividends, making } \\
\text { wrong } \\
\text { inefficient use of } \\
\text { assets, loose of control } \\
\text { over assets }\end{array}$ & $\begin{array}{l}\text { Principal's } \\
\text { costs in case of } \\
\text { the } \\
\text { opportunistic } \\
\text { behaviour of } \\
\text { an agent and } \\
\text { unfair } \\
\text { corporate } \\
\text { management }\end{array}$ \\
\hline $2,3,10$ & $\begin{array}{l}\text { Investor - } \\
\text { investment } \\
\text { users (emitters, } \\
\text { targeted budget } \\
\text { funding users) } \\
\text { (investment } \\
\text { transactions) }\end{array}$ & $\begin{array}{l}\text { Investments } \\
\text { and efficient } \\
\text { management } \\
\text { of them, } \\
\text { targeted use } \\
\text { of investment } \\
\text { sources }\end{array}$ & $\begin{array}{l}\text { Sanction risk for } \\
\text { violation of financial } \\
\text { and budget laws, } \\
\text { emitter's winding up, } \\
\text { business reputation } \\
\text { damage at the } \\
\text { financial market, } \\
\text { disinvest }\end{array}$ & $\begin{array}{l}\text { Emitter's costs for } \\
\text { information } \\
\text { disclosure, } \\
\text { obligation } \\
\text { performance, } \\
\text { monitoring and } \\
\text { control over } \\
\text { targeted use of } \\
\text { funds, resolution } \\
\text { of conflict of } \\
\text { interests }\end{array}$ & $\mid \begin{array}{lrr}\text { Investment } & \text { and } & \text { credit } \\
\text { risks } & \text { caused } & \text { by } \\
\text { falsified } & & \text { financial } \\
\text { information, } & \text { non- } \\
\text { performing } & & \text { loans } \\
\text { (creditors), } & \text { profit } \\
\text { decrease } & \text { on } & \text { the } \\
\text { invested } & \text { capital, } \\
\text { emitter } & \text { bankruptcy, } \\
\text { budget } & \text { expenses } \\
\text { increase, } & \text { reduction of } \\
\text { foreign } & & \text { direct } \\
\text { investments } & \text { in } \\
\text { economy (state) } & \end{array}$ & $\begin{array}{l}\text { Investor's } \\
\text { costs in case of } \\
\text { the } \\
\text { opportunistic } \\
\text { behaviour of } \\
\text { an agent and } \\
\text { nonfeasance of } \\
\text { investment } \\
\text { projects and } \\
\text { projects } \\
\text { sponsored } \\
\text { from } \\
\text { budget }\end{array}$ \\
\hline 4 & $\begin{array}{l}\text { Cluster } \\
\text { management } \\
\text { company -a } \\
\text { cluster resident } \\
\text { (management } \\
\text { transaction) }\end{array}$ & $\begin{array}{l}\text { Resources } \\
\text { management, } \\
\text { distribution } \\
\text { of } \\
\text { investment, } \\
\text { sources of } \\
\text { funding, joint } \\
\text { possession } \\
\text { and } \\
\text { management } \\
\text { of assets }\end{array}$ & $\begin{array}{l}\text { Risk of cluster } \\
\text { organisation } \\
\text { requirement violation, } \\
\text { misuse of subsidies } \\
\text { and other resources } \\
\text { dedicated to the } \\
\text { cluster, business } \\
\text { reputation damage, } \\
\text { financing decrease, } \\
\text { exclusion from the } \\
\text { cluster, company } \\
\text { liquidation }\end{array}$ & $\begin{array}{l}\text { Obligation } \\
\text { performance } \\
\text { costs, monitoring } \\
\text { and control } \\
\text { organisation, } \\
\text { protection from } \\
\text { the third party, } \\
\text { resolution } \\
\text { conflict } \\
\text { interests }\end{array}$ & $\begin{array}{l}\text { Risk not to fulfil } \\
\text { cluster operation } \\
\text { targets, of illegal right } \\
\text { to use intellectual } \\
\text { property, risk not to } \\
\text { implement investment } \\
\text { strategy }\end{array}$ & $\begin{array}{l}\text { Costs in case } \\
\text { of } \\
\text { opportunistic } \\
\text { behaviour of } \\
\text { cluster } \\
\text { residents and } \\
\text { misuse of } \\
\text { investment for } \\
\text { cluster } \\
\text { development }\end{array}$ \\
\hline $6-9$ & $\begin{array}{l}\text { Buyer - seller } \\
\text { (trade } \\
\text { transaction) }\end{array}$ & $\begin{array}{l}\text { Quality, } \\
\text { volume of } \\
\text { goods (work, } \\
\text { services) } \\
\text { payment and } \\
\text { other terms of } \\
\text { a contract, } \\
\text { fair behaviour } \\
\text { at the market }\end{array}$ & $\begin{array}{l}\text { Sanction risk owing } \\
\text { to trade, } \\
\text { antimonopoly, civil, } \\
\text { custom law violation, } \\
\text { in state purchasing, } \\
\text { risk of damage } \\
\text { payment, court costs, } \\
\text { business reputation } \\
\text { damage at a trade } \\
\text { market including } \\
\text { markets in foreign } \\
\text { countries, lower } \\
\text { demand for goods, } \\
\text { the loose of }\end{array}$ & \begin{tabular}{l|} 
Costs of \\
seller/buyer for \\
obligation \\
performance \\
(transformation \\
costs), monitoring \\
and control over \\
trade transaction, \\
protection from \\
the third party, \\
resolution of \\
conflict of \\
interests
\end{tabular} & $\begin{array}{l}\text { Risk of income loss, } \\
\text { belongings, life } \\
\text { standard decrease (for } \\
\text { population) during } \\
\text { transaction with unfair } \\
\text { organisations (socially } \\
\text { significant } \\
\text { organisations), } \\
\text { obligation breach, } \\
\text { corruption risk, export } \\
\text { decline, shadow } \\
\text { economy growth (for a } \\
\text { state), unfair } \\
\text { competitativeness, }\end{array}$ & $\begin{array}{l}\text { Costs of } \\
\text { buyer/seller in } \\
\text { case of the } \\
\text { opportunistic } \\
\text { behaviour of } \\
\text { an agent and } \\
\text { non- } \\
\text { compliance of } \\
\text { trade } \\
\text { transaction } \\
\text { conditions }\end{array}$ \\
\hline
\end{tabular}




\begin{tabular}{|c|c|c|c|c|c|c|}
\hline \multirow[t]{2}{*}{$\begin{array}{l}\text { Number of } \\
\text { transaction* }\end{array}$} & \multirow[t]{2}{*}{$\begin{array}{l}\text { Transaction } \\
\text { subjects }\end{array}$} & \multirow{2}{*}{$\begin{array}{l}\text { Possible } \\
\text { conflict of } \\
\text { interests }\end{array}$} & \multicolumn{2}{|c|}{$\begin{array}{c}\text { Economic agents and internal } \\
\text { stakeholders }\end{array}$} & \multicolumn{2}{|c|}{ External stakeholders } \\
\hline & & & Compliance risks & Transaction costs & Risks & $\begin{array}{l}\text { Transaction } \\
\text { costs }\end{array}$ \\
\hline & & & $\begin{array}{l}\text { significant } \\
\text { counteragents, } \\
\text { counteragent } \\
\text { liquidation }\end{array}$ & & $\begin{array}{l}\text { unfair performance of } \\
\text { state orders }\end{array}$ & \\
\hline 12 & $\begin{array}{l}\text { Financial and } \\
\text { non-financial } \\
\text { sector, } \\
\text { households - a } \\
\text { state (rationing } \\
\text { transaction) }\end{array}$ & $\begin{array}{l}\text { Payment of } \\
\text { tax and other } \\
\text { compulsory } \\
\text { payments, } \\
\text { customs } \\
\text { duties, fees, } \\
\text { punitive } \\
\text { damages }\end{array}$ & $\begin{array}{l}\text { Sanction risk for tax } \\
\text { law violation, loose of } \\
\text { trust from investors } \\
\text { and consumers }\end{array}$ & $\begin{array}{lrr}\text { Costs } & \text { for } & \text { tax } \\
\text { account } & & \text { and } \\
\text { control, } & & \text { for } \\
\text { cont } \\
\text { sanction } & \text { payment } \\
\text { as a result } & \text { of law } \\
\text { violation } & \end{array}$ & $\begin{array}{l}\text { Budget profit decrease } \\
\text { risk as a result of non- } \\
\text { payment of taxes }\end{array}$ & $\begin{array}{l}\text { State costs of } \\
\text { organisation, } \\
\text { provision of a } \\
\text { qualified } \\
\text { mechanism of } \\
\text { a state tax } \\
\text { control }\end{array}$ \\
\hline 13,15 & $\begin{array}{l}\text { Principal } \\
\text { (owner/compan } \\
\text { y management) } \\
\text { - internal } \\
\text { controller-- } \\
\text { agent } \\
\text { (management } \\
\text { transaction) }\end{array}$ & $\begin{array}{l}\text { Service } \\
\text { quality and } \\
\text { efficiency, } \\
\text { other terms of } \\
\text { a contract, } \\
\text { belongings } \\
\text { safety, } \\
\text { rational use } \\
\text { of resources }\end{array}$ & $\begin{array}{l}\text { Sanction risk for the } \\
\text { absence of internal } \\
\text { control, disciplinary } \\
\text { sanction for non- } \\
\text { compliance of labour } \\
\text { functions (internal } \\
\text { controller) }\end{array}$ & \begin{tabular}{|ll} 
Internal & control \\
costs, & quality \\
provision & \\
& \\
&
\end{tabular} & $\begin{array}{lr}\text { Risk of } & \text { wrong } \\
\text { management } & \text { decision } \\
\text { making, } & \text { costs, } \\
\text { damages } & \end{array}$ & $\begin{array}{l}\text { Stakeholders' } \\
\text { costs in case of } \\
\text { opportunistic } \\
\text { behaviour of } \\
\text { an organisation } \\
\text { and due to } \\
\text { internal control } \\
\text { absence }\end{array}$ \\
\hline 14 & $\begin{array}{l}\text { State-state } \\
\text { control service } \\
\text {-economic } \\
\text { agent } \\
\text { (management } \\
\text { transaction) }\end{array}$ & $\begin{array}{l}\text { Legal } \\
\text { standard } \\
\text { performance } \\
\text { when } \\
\text { conducting } \\
\text { control } \\
\text { activity }\end{array}$ & $\begin{array}{l}\text { Risk to be prosecuted } \\
\text { for poor performance } \\
\text { of } \\
\text { workers }\end{array}$ & $\begin{array}{l}\text { State costs for } \\
\text { organisation, } \\
\text { quality provision } \\
\text { of a state control } \\
\text { mechanism }\end{array}$ & $\begin{array}{l}\text { Risks to loose profit, } \\
\text { assets at transactions } \\
\text { with an unfair } \\
\text { organisation }\end{array}$ & $\begin{array}{l}\text { Stakeholders' } \\
\text { costs in case of } \\
\text { opportunistic } \\
\text { behaviour of } \\
\text { state } \\
\text { controllers, } \\
\text { agents }\end{array}$ \\
\hline 16 & $\begin{array}{l}\text { Principal/comp } \\
\text { any } \\
\text { management - } \\
\text { external auditor } \\
\text { - agent (trade } \\
\text { transaction) }\end{array}$ & $\begin{array}{l}\text { Service } \\
\text { quality and } \\
\text { efficiency, } \\
\text { other terms of } \\
\text { a contract }\end{array}$ & 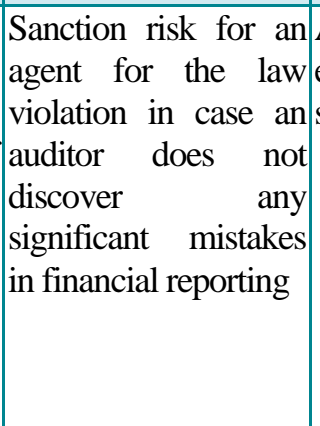 & $\begin{array}{lll}\text { Agent costs for } & \\
\text { external } & \text { auditor } \\
\text { services } & & \\
& & \\
1 \\
1 \\
\end{array}$ & $\begin{array}{l}\text { Sanction risk for low- } \\
\text { quality audit (auditor), } \\
\text { risk to make wrong } \\
\text { management decisions } \\
\text { (stakeholders) }\end{array}$ & $\begin{array}{l}\text { Stakeholders' } \\
\text { costs in case of } \\
\text { opportunistic } \\
\text { behaviour of } \\
\text { an agent and } \\
\text { low-quality } \\
\text { audit; auditor's } \\
\text { costs for } \\
\text { service quality } \\
\text { control }\end{array}$ \\
\hline
\end{tabular}

Note: * Number of transaction according to Fig. 1.

When committing a transaction, agents and their stakeholders run the risks of sanctions, risks to loose the income. It is necessary to forecast and prevent these risk possibilities using tools of a state, internal and external compliance control. The reduction of compliance risks, transaction costs of stakeholders and economic agents that are involved in transactions with socially significant organisations determines the economic profit from the efficient operation of this institution of control. Efficient legislation control and fair implementation of contract terms by socially significant organisations will protect all interested parties from compliance risks, ineffective use of investments and budgetary funds that are used for strategic programs implementation. It will also protect from the non-compliance of social projects significant for the state and society. Both a state, which provides sustainable balanced development of the national economy, and organisations, which realise their targets and are 
trying to increase their investment attractiveness, are interested in an efficient mechanism of the compliance control.

Efficiency of an institute in the institutional theory is known to be achieved by the decrease of private and public costs for an institute organisation and functioning. Institutions are considered to be efficient if they allow "the outsiders to assess the business affairs as easily as the insiders do, i.e. institutes that guarantee transparent corporate management are all that is necessary to decrease transaction costs and to facilitate transactions with property rights" [7]. Consequently, the compliance control institute will be efficient if all functions of the institution are totally fulfilled and transaction costs of participants of institutional relations are reduced.

The functions of the compliance control institution focus on provision and protection of interests of socially significant organisations and of all stakeholders. We distinguish the following functions: organizing, restrictive, coordinating, informational, regulatory, distribution and simulative (Fig. 2).

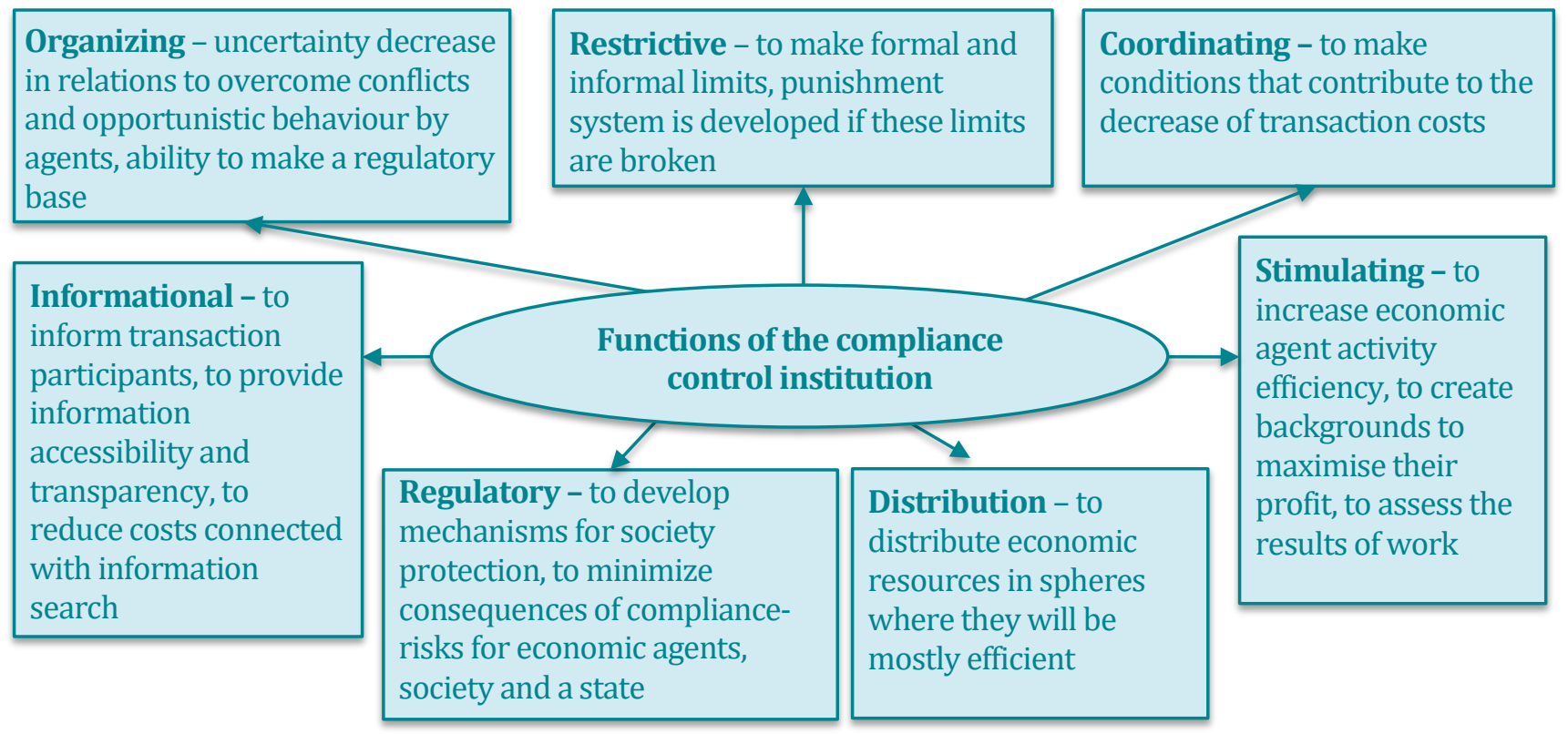

Fig. 2. Complex of compliance control institution functions

The implementation of the compliance control institution contributes into the adaptation of the control over rules and norms of economic agents' behaviour at the market in the society. The absence or non-compliance of this or that function leads to disbalance of the institutional system, poor quality of the control, inefficiency of control measures, resource productivity decrease.

The efficiency of the compliance control institution should contribute to resources displacement from some economic agents to others stimulating their efficient use. That will allow society to achieve prosperity in general. Transaction control of socially significant organisations is necessary to distribute resources efficiently, to send investments to the economic agents that observe standards and norms of behaviour, conscientiously bargaining, use own and borrowed funds efficiently, perform liabilities in time. Thus, the aim of the compliance-control institution is to reveal, assess risks of opportunistic behaviour of transaction participants, to prevent negative consequences for economy that will prevent the disbalance of economic interests of all participants. Meanwhile the efficient control mechanism is the basis for the formation of the society economic culture, of trust among the state, socially significant organisations and population restricting the behaviour of participants of institutional relations and developing fair attitude to resource use.

Substantial and functional-targeted definition of the compliance control characterises the present institute structure. 


\section{Institutional structure of the compliance control}

s has been mentioned above the
institute of compliance control
consists of a complex of formal and informal norms that are described in standards, methodological guidelines, instructions that determine the order of actions and relations among agents operating in the institutional environment to provide social and economic stability of the society. Formal and informal institutions determine the economic behaviour rules, limits for economic agents. On this basis the institutional structure of the compliance-control is made by:

- compliance control organisations that are authorized to conduct control activity on public normative, ethic and methodical rules developed by the state authorities and professional communities;

- laws and regulations confirmed at the legislative level and local acts that assign organisations to make the compliance control;

- enforcement mechanisms (sanctions for non-performance of compliance control rules, job description, ethical standards; control of quality and testing of control procedure efficiency);

- guarantors of execution (state authorities and professional self-regulated organizations that assess quality).

Thus, the institute of the compliance control has a complex structure that includes state control authorities, independent audit firms and internal services of economic agents that are authorized by functions to reveal compliance risks and to prevent economic crimes.

The authorities providing the state compliance of socially significant organisations and being subjects of the institute are Accounts Chamber of the Russian Federation (sate companies and state corporations), the Federal Treasury (control of budget funds spending), the Central Bank of the Russian Federation and Federal Financial Monitoring Service (bank, currency, anti-corruption compliance of financially significant organisations), FAS (antimonopoly compliance of socially significant and other organisations), FCS (costumes compliance of export-oriented organisations), FTS (tax compliance), etc. Institutional norms of the state compliance are enshrined in laws, internal regulation services, standards, ethic rules and other documents. For instance, Accounts Chamber of the Russian Federation relies on the International Standards of Supreme Audit Institutions in the compliance control field (ISSAI 4000-4999).

Let's discuss the forms of an external audit and internal compliance control in detail. These forms together with the state control make the compliance-control system in Russia.

The task of an independent external audit in the market economy is to reduce transaction costs and information risks of stakeholders. This type of audit acts on behalf of an owner and other interested parties, the list of them may be unlimited and unknown in advance in case of the published financial reporting. Standardization, high requirements to qualification of specialists and their market entry in the audit profession, enforcement of socially significant organisations to compulsory audit, high responsibility and quality control when auditors compliance with standards and ethic rules make the audit of financial reporting sustainable and effective public institution. Its efficiency is achieved by a constantly operating mechanism of quality assurance of auditors' work. V.L. Tambovtsev stresses that the more institutional environment of the economy consists of effective rules, the more opportunities appear for its successful operation, the less unproductive costs and risk for all economic agents are there [20]. Rules (norms) of an independent audit are enshrined in the audit activity law - the standards that are being developed and changed by International Federation of Accounts (IFAC), the norms of professional ethic and rules of independent auditors, the standards of self-regulated organisations, internal regulations of auditing organisations. Audit standards are the enforcement mechanism to the principles of financial reporting, to the conduction of an internal control and to the fraud and corruption control. Moreover, the quality control of auditor's services on behalf of professional communities and enforcement authorities increases the efficiency. The institutional norms that are reporting authenticity existing in the 
audit system (ISA 2405 $250^{6}$, Auditors development program $^{7}$, Methodological guidelines on anti-corruption activity organized and conducted by audit organizations and individual auditors ${ }^{8}$ ) reveal compliance risks and estimate the system of internal control.

Compliance function is considered to be an assistant for an owner or management to reveal and reduce compliance-risks, to minimise their consequences in case of the control by the state authorities. Owners have significant resources and determine basic concept of an economic agent activity, have a right to get dividends and, as a rule, consider an organisation as a tool to maximise the profit from their investments. There is a risk of "incomplete contracts" in case of information asymmetry. In this case an agent activity is not directly observed by a principal and it is impossible to assess by the final results. It may lead to opportunism. Corporate control by an owner that stimulates to internal and external control should guarantee the other stakeholders' interests compliance. These stakeholders are interested in the legitimate activity of an economic agent, the opportunistic risk decrease but do not have an individual access to the information. Commercial banks assessing creditworthiness of a potential creditor should rely on financial reporting confirmed by independent auditors as the creditor's compliance risks may increase credit risks of banks. Stock exchanges making securities listing of public companies according to the Central Bank of the RF Regulation № 473- $\mathrm{P}^{9}$ provide

\footnotetext{
${ }^{5}$ Auditor's duties in regard to fraud at auditing of financial reporting: international standards on auditing 240: introduced by Ministry of Finance of the RF on 24.10.2016 № 192 n.

${ }^{6}$ International standards on auditing (ISA) 250 «Consideration of laws and legal acts during financial reporting audit» (enacted on the territory of the RF by the order of Ministry of Finance of the RF on 24.10.2016 № 192n).

${ }^{7}$ Auditors development program № PK-5-010-2009 «Anticorruption during audit»: confirmed by the order of Ministry of Finance of the RF on March, 10, 2009 № 21n.

${ }^{8}$ Methodoligical guidelines on anti-corruption activity organised and conducted by audit organisations and individual auditors: approved by auditor activity council on 23.09.2015.

${ }^{9}$ Regulations on the tender activity: confirmed by the Central Bank of the RF on 17.10.2014 № 437-P.
}

the accessibility of financial and non-financial information of emitters. The authenticity of this data is confirmed by auditors. It is necessary for real and potential investors, creditors and other interested parties for decision-making.

Meanwhile, there are some objective factors when an auditor is not confident about the compliance-risks during reporting authenticity checking:

- ISA 250 makes a clause that during auditing the correspondence to laws and regulations that are related to financial information and reporting is assessed. The purpose of audit is not to prevent cases when an auditor does not adhere to legislation, to qualify a particular action (inaction) as a noncompliance of regulatory instruments;

- low rate of unfair action revelation in case management or an owner is involved in them;

- the urgency of information that proves violation is reduced as an audit has a form of a follow-up control;

- if an auditee does not have an internal control system, features of bookkeeping, transaction costs of an auditor to collect and analyse evidence-based economic crimes increase;

- specific character of frauds that are accompanied by documents falsification that is purposefully complicated and disguised by schemes. An auditor may not pay attention to these schemes but it makes auditing of deliberate distortions inefficient (cl. A47 ISA $200^{10}$ ). It is written in the standards that an auditor is not obliged to check the documents authenticity, does not have an appropriate training, legal rights for searching or other procedures necessary for the investigation and intention;

- if the risk of unfair actions or corruption is revealed, an auditor is motivated to inform the management or an owner and rarely law enforcement bodies about it.

Compliance-audit that suggests checking the performance of all laws and regulations that

\footnotetext{
${ }^{10}$ International standards on auditing (ISA) 200 «Main purposes of an independent auditor and auditing in accordance to international standards» (enacted by the order of Ministry of Finance of the RF on 24.10.2016 № 192n).
} 
impact the socially significant organisation activity may be wholly realised on the initiative of a person responsible for corporate management, of law enforcement bodies in terms of the task that provides confidence $\left(\right.$ IFAE $3000^{11}$ ) or coordinated procedure (ISRS $4400^{12}$ ).

Internal compliance control becomes also important for socially significant organisations together with external compliancecontrol. It allows organising and involving countering tools to external and internal environment damages. Institutional norms and mechanisms of internal control enforcement include:

- legislative and methodical norms for financially significant organisations (e.g. Regulation № 242- $\mathrm{P}^{13}$, The letter of the Central Bank of the RF dated 30.06.2005 № 92-T, “The letter of the Central Bank of the RF dated 02.11.2007 № 173-T "About the recommendations by Basel Committee on Banking Supervision" ("Compliance and compliance function in banks"), The Federal law dated 07.08.2001 № 115-FZ (ed. on 29.07.2017) "On counteraction the legalization (laundering) of incomes obtained in a criminal way, and terrorism financing"). The state is very interested in the institute of compliance control for financially significant organisations because the increase of bank opportunism, unprofessional relations with bank clients, laundering of income that was earned by criminal way threaten the national economy security;

- the ways of internal compliance introduction and organisation that are applied on an economic agent management initiative to counteract high risks of control on behalf of enforcement authorities, sanctions for tax and corruption law breaking, investment and

\footnotetext{
${ }^{11}$ International Framework for Assurance Engagements 3000 «Tasks providing confidence and different from auditing and reviewing of financial information of previous periods» (enacted by the order of Ministry of Finance of the RF dated 24.10.2016 № 192n).

${ }^{12}$ International Standard on Related Services 4400 «Tasks to conduct coordinated procedures regarding financial information» (enacted by the order of Ministry of Finance of the RF dated 24.10.2016 № 192n)

${ }^{13}$ Regulation on internal control in credit organisations and banking groups, confirmed by the Central Bank of the RF on 16.12.2003 № 242-P
}

borrowed funds losses. The law about accounting $^{14}$ obliges organisations to conduct internal control of economic activity facts but does not entrench the obligation to implement compliance control in the FL № 115-FZ. A set of institutional norms operates in the part of an internal control. They are Recommendations of Ministry of Finance of the $\mathrm{RF}^{15}$, Methodological guidelines for internal auditing in stock companies with state participation ${ }^{16}$, standards of COSO and other international organisations, internal corporate standards.

In spite of compliance norms and enforcement mechanisms there are factors that cause the institute dysfunctions:

- formal attitude to norms and low interest to internal compliance organisation and the involvement of an independent auditor. It happens because the contribution of audit in the national economy development is underestimated, social corporate responsibility is unrecognised and also due to an insider model of management. It results in opportunistic behaviour increase and corruption greatly influences the economy in general;

- the absence of official status of international standards of internal audit and compliance control in Russia increases transaction costs of economic agents on the working out of corporate standards and methodical guidelines. This fact restrains the formation of the compliance institute;

- the absence of the system of requirements to compliance control quality and its assessment mechanisms on behalf of state authorities and professional communities;

- imperfection of scientific and methodical base that requires the refinement of

\footnotetext{
${ }^{14}$ About accounting: Federal law dated 06.12.2011 № 402FZ.

${ }^{15}$ Organisation and implementation of an internal control of economic activity facts, accounting and bookkeeping of financial reporting by an economic agent: information of Ministry of Finance of the RF № PZ-11/2013.

${ }^{16}$ Confirmation of Methodological guidelines for internal auditing in stock companies with the RF participation: the order of the Federal Agency for State Property Management dated 04.07.2014 № 249; Confirmation of Methodological guidelines for internal auditing functions in holding structures with the RF participation: the order of the Federal Agency for State Property Management dated 03.09.2014 № 330 .
} 
the compliance-risk system, their classification based on the reasons and consequences, identification methods, algorithms to prove the unfair behaviour. In this regard the issues concerning the development of compliance methodology based on the review of modern practical experience in the field of economic criminal investigations, possible schemes and estimation of the consequences of impact, calculation of economic damage for interested parties are acute.

To make the compliance control institution efficient for socially significant organisations we need measures to destabilize the factors negatively influencing its development.
Besides it is necessary to assist in the economic development strategy implementation in longterm perspective by increasing compliance efficiency and cooperation among state, business and society. It is important to increaser demands on behalf of investors, creditors and society that would motivate to internal and external compliance-control. Compliance control being an institute is an integrated mechanism that focuses on revelation, prevention and suppressing of financial and non-financial risks that may occur when an organisation interacts with an environment. We suggest the classification of compliance control for organisation groups taking into account possible compliance risks (Table 3 ).

Table 3

\section{Classification of compliance control of socially significant organisations}

\begin{tabular}{|c|c|c|c|c|c|c|c|c|c|}
\hline \multirow[b]{2}{*}{$\begin{array}{l}\text { Types of } \\
\text { compliance } \\
\text { control }\end{array}$} & \multirow[b]{2}{*}{ Definition } & \multicolumn{8}{|c|}{ Groups of socially significant organisations } \\
\hline & & 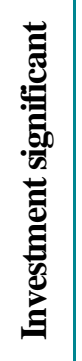 & 总 & 离 & 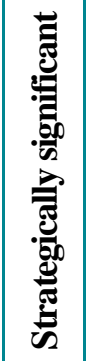 & 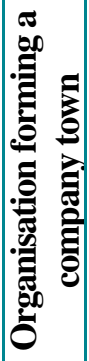 & 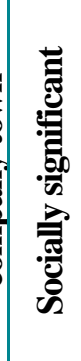 & 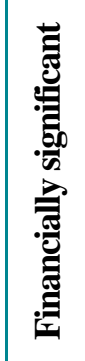 & 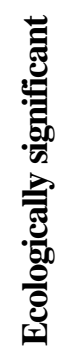 \\
\hline Investment & $\begin{array}{l}\text { To control legality and expediency of securities emitter activity, } \\
\text { of interrelated organisations in the field of fair behaviour at the } \\
\text { securities market, the targeted use of investments and the } \\
\text { implementation of investment projects, payments among } \\
\text { interrelated organisations in order to reduce investor risks and } \\
\text { to increase investment attractiveness }\end{array}$ & & & + & & & & & \\
\hline $\begin{array}{l}\text { Anti- } \\
\text { corruption }\end{array}$ & $\begin{array}{l}\text { To control the compliance of anticorruption principles and rules }+ \\
\text { and legalisation of profits got illegally. It should be done to } \\
\text { reveal the reasons, possibilities and ways of abuse, financial } \\
\text { crimes }\end{array}$ & & + & + & + & & + & + & \\
\hline Customs & $\begin{array}{l}\text { To control the compliance of customs legislation, principles } \\
\text { and norms of international trade, whether customs payments } \\
\text { were made totally and in time in external-economic contracts }\end{array}$ & & + & & & & & & \\
\hline Innovative & $\begin{array}{l}\text { To control the compliance of laws, treaty commitments, } \\
\text { agreements concerning the use of intellectual property objects, } \\
\text { funds of venture capital financing, when producing and selling } \\
\text { innovation goods, innovation measures implementation }\end{array}$ & & & & + & & & & \\
\hline Budget & $\begin{array}{l}\text { To control the compliance of laws during receiving and } \\
\text { targeted use of budget funds, other properties when } \\
\text { implementing federal (regional) programs, socially significant } \\
\text { projects, state purchasing and orders in order to reduce risks of } \\
\text { unfair use of federal (subjects of the federation and municipal) } \\
\text { properties or budget funds }\end{array}$ & & & + & + & + & + & & \\
\hline Strategic & $\begin{array}{l}\text { To control whether economic agent activity corresponds to the } \\
\text { plans and programs of economic development, to the } \\
\text { implementation of agreements and trends of economic policy at } \\
\text { federal and regional levels }\end{array}$ & & & + & + & + & & & \\
\hline
\end{tabular}


The End of Table 3

\begin{tabular}{|c|c|c|c|c|c|c|c|c|c|}
\hline \multirow[b]{2}{*}{$\begin{array}{l}\text { Types of } \\
\text { compliance } \\
\text { control }\end{array}$} & \multirow[b]{2}{*}{ Definition } & \multicolumn{8}{|c|}{ Groups of socially significant organisations } \\
\hline & & 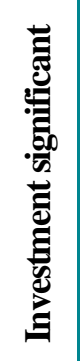 & 总 & 常 & 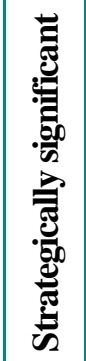 & 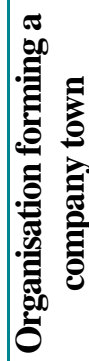 & 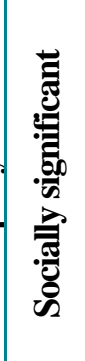 & 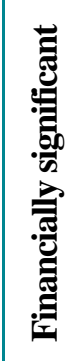 & 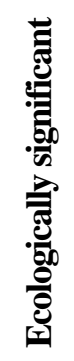 \\
\hline Tax & $\begin{array}{l}\text { To control the compliance of tax legislation, the order of } \\
\text { calculation and payment of compulsory payments to the } \\
\text { budget, execution of contractual relations, the accuracy and } \\
\text { reliability of the information specified in the primary } \\
\text { documents and tax registers, whether tax declarations are filed } \\
\text { in time to reduce tax risks }\end{array}$ & & + & + & + & + & + & + & + \\
\hline Antitrust & $\begin{array}{l}\text { To control fair behaviour of an economic agent at trade and } \\
\text { financial markets, the price policy and fair competitiveness } \\
\text { compliance }\end{array}$ & & + & & + & & + & & \\
\hline Staff & $\begin{array}{l}\text { To control the compliance of labour legislation and } \\
\text { performance of labour functions, whether employees } \\
\text { correspond to qualification demands }\end{array}$ & & + & + & + & + & + & + & \\
\hline Ecological & $\begin{array}{l}\text { To control the compliance of environmental legislation, } \\
\text { standards, financing and implementation of environmental } \\
\text { protection measures, the selection of environmentally friendly } \\
\text { materials for production and security in manufacturing }\end{array}$ & & & & & & & & + \\
\hline Banking & $\begin{array}{l}\text { To control the compliance of legislation, guidelines and other } \\
\text { documents of the Central Bank of the RF in order to check } \\
\text { whether the activity of credit and non-credit financial } \\
\text { organisations corresponds to the requirements }\end{array}$ & & & & & & & + & \\
\hline Inter-cluster & $\begin{array}{l}\text { To control whether the agreements on cluster development, } \\
\text { integrated programs of regional and branch cluster policy, } \\
\text { targeted use of financial resources and their reasonable division } \\
\text { among participants, joint ownership of assets (including } \\
\text { intellectual property) are fulfilled in order to efficiently manage } \\
\text { an innovation cluster }\end{array}$ & & & & + & & & & \\
\hline
\end{tabular}

The types of compliance control described in Table 3 should be specified in methodical toolkit of internal, external audit and state control of socially significant organisations due to their specificity and importance of compliance risks during transactions. The analysis of formal and informal institutes of compliance control has revealed that they make a single structure that requires particular interaction of control subjects. Factors that prevent the institute function implementation should be excluded as well. It is necessary to build a hierarchy structure of the institute with clear division of internal and external control tasks to form the compliance control system. It is also important to develop a decision complex to realise the institute functions successfully and to increase its efficiency.

\section{Conclusion}

7 make the national economy function efficiently the interests of economic agents who realise transactions should be coordinated, their conflicts with stakeholders should be minimised, the risks of external factors that affect the achievement of organisation purposes should be forecasted and the threats to the society welfare should be reduces.

Socially significant organisations bear losses and bankruptcy risks as well as the state and society in general have damages in case there is a lack of goods demand, of financial investments, transparent structure of property. It 
also happens if contract terms are broken and the quality of goods and services is poor. They have losses since significant resources are wasted, corruption increases and most employees working at these organisations become jobless.

Economic nature of the compliance control as an institute may be expressed in the following statements:

- the compliance control institute is a complex of organisations, the participants of which interact with each other on the basis of norms that regulate their ethic, organisational and methodical principles;

- the compliance control institute function is to check whether the activity of socially significant organisations corresponds to laws and regulations and business practice standards, reducing opportunistic behaviour risks and negative impact on stakeholders' interests. The state and society are the main stakeholders;

- the compliance control institute reduces transaction costs of institutional relation participants, that influences the economy sustainable development;

- the compliance control institute restricts the stakeholders' decision making concerning investments or other interaction with an economic agent at resources distribution.
The economic efficiency of the compliance-control institute consists in the complete implementation of the main functions of the institute (organisational, restrictive, coordinating, information, regulating, distribution and motivation) and in the decrease of compliance risks of both socially significant organisations and their stakeholders to minimize the national economy losses from the opportunistic behaviour of transaction subjects.

The institute of compliance control has not been completely formed in Russia. It is just on the initial stage of the development. There are factors that restrict its successful functioning leading to the growth of transaction costs connected to the overcome of the inefficient activity of the institute. Scientific studies devoted to the compliance control development and its institutional mechanism should be aimed at the revelation of dysfunctions that prevent the institute efficient operation. The researches should also concentrate on the forecast of losses in economy caused by inefficient control mechanisms. Theoretical and methodological basis of the compliance-control should be developed and improved at all levels of the system, the conditions for implementation and interaction of particular forms and directions of control should be provided. That is the purpose of our further studies.

\section{References}

1. Valiev V.Kh. Komplaens-funktsiya $\mathrm{v}$ sovremennykh predpriyatiyakh pridorozhnogo servisa, kak odin iz effektivnykh metodov upravleniya riskami [The compliance function in modern roadside service enterprises as one of the most effective methods of risk management]. Sovremennye problemy nauki i obrazovaniya [Modern Problems of Science and Education], 2015, no. 2-2, pp. 390-399. (In Russian).

2. Silakova V.V. Komplaens v sisteme risk-menedzhmenta nepreryvnykh proizvodstv [Compliance in the system of risk management of continuous production]. Ekonomika $i$ upravlenie: problemy, resheniya [Economics and Management: Problems, Solutions], 2015, no. 9, pp. 96-104. (In Russian).

3. Starinov G.P., Tseveleva I.V. Komplaens-programma v sisteme upravleniya deliktnymi riskami predpriyatiya [Compliance-program in a tort risk enterprise management system]. Vestnik Vladimirskogo yuridicheskogo instituta [Bulletin of Vladimir Law Institute], 2016, no. 3 (40), pp. 115-119. (In Russian).

4. North D.C. Institutions, transaction costs, and the rise of merchant empires. In book: The political economy of merchant empires. Ed. by J. Tracy. Cambridge, Cambridge University Press, 1991. pp. 161-195.

5. Kleiner G.B. Evolyutsiya institutsional'nykh sistem [Evolution of institutional systems]. Moscow, Nauka Publ., 2004. 240 p. (In Russian).

6. Hodgson G.M. The approach of institutional economics. Journal of Economic Literature, 1998, vol. 36, iss. 1, pp. 166-192.

7. Itygilova E.Yu. Institutsional'nye aspekty audita bukhgalterskoi finansovoi otchetnosti [Institutional aspects of audit of financial Aaccounting]. Mezhdunarodnyi bukhgalterskii uchet [International Accounting], 2015, no. 29 (371), pp. 29-49. (In Russian). 
8. Institutsional'nye aspekty bukhgalterskogo ucheta $i$ kontrolya [Institutional aspects of accounting and control]. Ed. by V.V. Pankov, V.I. Perov. Moscow, GOU VPO "REA imeni G.V. Plekhanova” Publ., 2009, 428 p. (In Russian).

9. Baranov P.P. Ugroza utraty institutsional'nogo statusa auditorskoi deyatel'nosti $\mathrm{v}$ usloviyakh stagnatsii teorii audita [Threat to auditor activity to loose the institutional status in the conditions of stagnation of the audit theory]. Sibirskaya finansovaya shkola [Siberian Financial School], 2012, no. 6 (95), pp. 144-150. (In Russian).

10. Zhukov V.N. Ekonomicheskie teorii, opredelyayushchie kontury razvitiya vnutrennego finansovogo kontrolya [Economic theories that determine the contours of the internal financial control development]. Finansovaya analitika: problemy i resheniya [Financial Analytics: Science and Experience], 2014, no. 42 (228), pp. 36-47. (In Russian).

11. Commons J.R. Institutsional'naya ekonomika. Per. s angl. A.A. Oganesyan. Nauch. red. V.M Efimov. [Institutional economics. Transl. from Engl. by A.A. Oganesyan. Scie. ed. V.M Efimov]. Terra Economicus [Terra Economicus], 2012, no. 3. pp. 69-76 (In Russian).

12. Williamson O.E. Ekonomicheskie instituty kapitalizma. Firmy, rynki, «otnoshencheskaya» kontraktatsiya. Per. s angl. [The economic institutions of capitalism. Firms, markets, "relative" contracting. Transl. from Engl.]. St. Petersburg, Lenizdat Publ., 1996. 702 p. (In Russian).

13. Alchian A., Demsets G. Proizvodstvo, informatsionnye izderzhki i ekonomicheskaya organizatsiya [Production, information costs and economic organization]. In book: Istoki: ekonomika v kontekste istorii i kul'tury. Vypusk 5 [Sources: Economics in the context of history and culture. Iss. 5]. Moscow, GU - VShE Publ., 2004, pp. 166-207. (In Russian). $385 \mathrm{p}$.

14. Eggertsson T. Economic behavior and institutions. Cambridge, Cambridge University Press, 1999.

15. Furubotn E.G., Richter R. The new institutional economics: An assessment. In book: The New Institutional Economics. Intr. and ed. by E.G. Furubotn, R. Richter. Texas A\&M University Press, College Station, 1991, pp. 1-32.

16. Shastitko A.E. Novaya institutsional'naya ekonomicheskaya teoriya. 4-e izd. [New institutional economic theory. The $4^{\text {th }}$ ed.]. Moscow, TEIS Publ., 2010. 827 p. (In Russian).

17. Coase R.H. Priroda firmy [The nature of the firm]. Vekhi ekonomicheskoi mysli. T. 2. Teoriya firmy [Milestones of Economic Thoughts. Vol. 2. A Firm Theory], 1999, vol. 2, pp. 11-32. (In Russian).

18. Freeman R.E., Martin K., Parmar B. Stakeholder Capitalism. Journal of Business Ethics, 2007, vol. 74, iss. 4, pp. 303-314.

19. Jensen M.C., Meckling W.H. Theory of the firm: Managerial behavior, agency costs and ownership structure. Journal of Financial Economics, 1976, vol. 3, iss. 4, pp. 305-360.

20. Institutsional'nye ogranicheniya ekonomicheskoi dinamiki [Institutional constraints of economic dynamics]. Scien. ed. V.L. Tambovtsev. Moscow, TEIS Publ., 2009. 524 p. (In Russian).

21. Sukharev O.S. Ekonomicheskaya teoriya institutsional'nogo modelirovaniya: printsipy i vozmozhnosti [Economic theory of institutional modeling: Principles and possibilities]. Zhurnal ekonomicheskoi teorii [Russian Journal of Economic Theory], 2017, no. 1, pp. 102-116. (In Russian).

22. Sotnikova L.V. Audit obshchestvenno znachimykh khozyaistvuyushchikh sub"ektov [Audit of socially significant economic entities]. Auditorskie vedomosti [Audit News], 2008, no. 6, pp. 45-52 (In Russian).

23. Galbraith J.K. Ekonomicheskie teorii i tseli obshchestva [Economics and public purpose]. Moscow, Progress Publ., 1979. 406 p. (In Russian).

24. Phillips R. Some key questions about stakeholder theory. Reprint № 9B04TB03. Ivey Business Journal, 2004, March/April, pp. 1-4. Available at: https://iveybusinessjournal.com/publication/some-keyquestions-about-stakeholder-theory/ (accessed 05.08.2017).

25. Veblen T. The theory of leisure class: An economic study of institutions. New York, B.W.Huebsh Publ., 1899. 412 p.

26. Dement'ev V.V. Chto my issleduem, kogda issleduem instituty? [What do we investigate when we investigate institutions?]. Ekonomicheskaya teoriya [Economic Theory], 2009, vol. 6, no. 3 (3-2009), pp. 75-93. (In Russian). 


\section{Information about the Author}

Yakimova Vilena Anatol'evna - Candidate of Economic Sciences, Associate Professor at Finance Department, Amur State University (21, Ignat'evskoe shosse, Blagoveshchensk, 675027, Russia; e-mail: vilena_yakimova@mail.ru).

\section{Сведения об авторе}

Якимова Вилена Анатольевна - кандидат экономических наук, доцент кафедры финансов, Амурский государственный университет (Россия, 675027, г. Благовещенск, ул. Игнатьевское шоссе, 21; e-mail: vilena_yakimova @mail.ru).

\footnotetext{
Просьба ссылаться на эту статью в русскоязычных источниках следующим образом:

Yakimova V.A. Substantiation of a compliance control of socially significant organisations on the institutional theory basis // Вестник Пермского университета. Сер. «Экономика» = Perm University Herald. Economy. 2017. Tом 12. № 4. C. 542-560. doi: 10.17072/1994-9960-2017-4$542-560$
}

Please cite this article in English as:

Yakimova V.A. Substantiation of a compliance control of socially significant organisations on the institutional theory basis. Vestnik Permskogo universiteta. Seria Ekonomika $=$ Perm University Herald. Economy. 2017, vol. 12, no. 4, pp. 542-560. doi: 10.17072/1994-9960-2017-4-542-560 